\author{
Jadwiga STĘCHEY ${ }^{1}$
}

\title{
ZABYKOWA STOLARKA DRZWIOWA W JAROSŁAWSKICH OBIEKTACH SAKRALNYCH
}

\begin{abstract}
Drzwi w obiektach sakralnych posiadają szczególne znaczenie, pełnią funkcję zabezpieczenia wnętrza, są ozdobą, wyznaczają granicę pomiędzy sacrum i profanum, urastają do rangi symbolu i znaku pamięci. Celem pracy jest zidentyfikowanie i rozpoznanie historycznej stolarki w obiektach sakralnych Jarosławia, jej analiza pod względem materiałoznawstwa, budowy konstrukcyjnej i technik zdobniczych, stylu i ikonografii, a także stanu zachowania. W jarosławskich obiektach sakralnych zachowały się jednostkowe drzwi barokowe z końca XVII i XVIII wieku, a także historyzujące drzwi z 2 poł. XIX i pocz. XX wieku. Barokową stolarkę wraz z oryginalnymi okuciami (zawiasami, hakami, klamkami, szyldami, zamkami, kłódkami, a nawet zachowanymi kluczami) reprezentują drzwi w kościółku pw. Świętego Ducha oraz kościele pw. Matki Bożej Bolesnej. Szczególną uwagę zwracają ażurowe drzwi w motywem IHS w snycerskiej oprawie znajdujące się w klasztorze dominikańskim. Duży zespół oryginalnej stolarki z ostatniej ćwierci XIX wieku zachował się w klasztorze Zgromadzenia Sióstr Niepokalanego Poczęcia NMP. Natomiast 1 poł. XX wieku reprezentują drzwi historyzujące, z motywami neobarokowej i rokokowej snycerki, znajdujące się w założeniu kościelnoklasztornym OO. Franciszkanów (OFM) oraz kolegiacie pw. Bożego Ciała. W skali wysokiej rangi obiektów sakralnych, jakie występują w Jarosławiu, zachowane oryginalne drzwi stanowią małą, aczkolwiek znamienną grupę, dlatego zasługują one na ochronę i podjęcie dalszych badań.
\end{abstract}

Słowa kluczowe: zabytkowa stolarka, drzwi, Jarosław, obiekty sakralne

\section{Wstęp}

Drzwi, bramy, furty w obiektach sakralnych posiadają szczególne znaczenie. Pełnią one nie tylko funkcję zabezpieczającą wnętrze i dekoracyjną, ale nade wszystko symboliczną. Oznaczają one zawsze granicę między sacrum i profanum, zarówno drzwi prowadzące do wnętrza kościoła, jak i te w furcie klasztornej oddzielające życie klauzurowe od świeckiego. Obecnie te granice się zacierają, ale wejście do każdego kościoła nadal symbolizuje samego Zbawiciela. „Ja jestem bramą dla owiec. Jeżeli ktoś wejdzie przeze Mnie, będzie zbawiony" powiedział

\footnotetext{
${ }^{1}$ Urząd Miasta Jarosławia, Rynek 1, e-mail: jagastechly@wp.pl
} 
Jezus (J 10,7) porównując się do bramy. ${ }^{2}$ Dlatego od wieków tak wielką wagę przywiązywano do drzwi, a niejednokrotnie portalu z tympanonem ujmującego wejście do świątyni. Często obrazowały one wydarzenia biblijne i historyczne, ważne w dziejach Kościoła lub kraju, w którym powstały. Warto przypomnieć tutaj drewniane drzwi bazyliki Św. Sabiny na Awentynie (V w.), brązowe Drzwi z Hildesheim (1015r.), Drzwi Gnieźnieńskie (XII w.), czy też Drzwi Raju w baptysterium we Florencji (1403-24). W Pontyficale Romanum dla drzwi przewidziane jest odrębne poświęcenie. Najpierw biskup puka trzykrotnie pastorałem w drzwi wołając: „Attollite portas principes vestras” - Podnieście, Książęta, bramy wasze, i podnieście się, bramy wieczne, a wnijdzie Król chwały” (Ps. 24, 7.9 - Wlg). Następnie biskup namaszcza drzwi krzyżmem, modląc się przy tym: „Bramo, bądź pobłogosławiona, poświęcona, opieczętowana i przeznaczona dla Pana Boga; bramo, bądź wejściem do zbawienia i pokoju; bramo, bądź wrotami pokoju, przez Tego, który sam się nazwa Bramą, Jezusa Chrystusa Pana naszego, który z Ojcem i Duchem Świętym żyje i króluje, Bóg przez wszystkie wieki wieków. Amen.”

Współcześni również przywiązują dużą wagę do formy kościelnych drzwi. Świadectwem są takie realizacje jak np. Drzwi Jubileuszowe Zofii Mitał do archikatedry w Przemyślu, Drzwi Papieskie Gustawa Zemły w konkatedrze św. Jakuba w Olsztynie (2001), czy drzwi Igora Mitoraja do kościoła jezuitów w Warszawie (2009). Drzwi nadal pełnią ogromną rolę i każdy fundując nowe chce pozostawić po sobie świadectwo. Nie zawsze ten nowy „pomnik” jest lepszy od starego. I niestety stare drzwi są wymieniane, bo nie znajduje zrozumienia konieczność zachowania historycznej stolarki drzwiowej w obiektach sakralnych, nawet jeżeli jej stan zachowania nie wyklucza dalszego użytkowania.

\section{Przedmiot i cel pracy oraz stan badań}

Chociaż w Jarosławiu znakomite założenia kościelno-klasztorne z XVII i XVIII wieku przetrwały, oryginalna stolarka w skali tych założeń, zachowała się w małym stopniu. Dominują drzwi z końca XIX i XX wieku, lecz w barokowych wnętrzach kościelnych, korytarzach klasztornych można jeszcze odnaleźć oryginalne obiekty ${ }^{4}$. $\mathrm{Z}$ uwagi na postępującą destrukcję materiału oraz panujące tendencje wymiany drzwi na nowe zasługują one na szczególną uwagę. Celem pracy jest zidentyfikowanie i rozpoznanie historycznej stolarki w obiektach sakralnych Jarosławia, jej analiza pod względem materiałoznawstwa, budowy konstrukcyjnej i technik zdobniczych, stylu ikonografii, a także stanu zachowania. Badania objęły kościół pojezuicki, obecnie kolegiatę pw. Bożego Ciała z końca XVI wieku,

\footnotetext{
${ }^{2}$ Szerzej na temat symboliki drzwi w sztuce kościelnej por. Forstner D. OSB, hasło: drzwi, w: Świat symboliki chrześcijańskiej, Warszawa 1990, s. 383-386; Lurker M., hasło: drzwi, w: Słownik obrazów i symboli biblijnych, Poznań 1989, s. 50-52; Miazek J. ks., Otwarcie drzwi świętych w Roku Jubileuszowym, Warszawskie Studia Teologiczne, T. XIII, 2000, s. 7-16.

${ }^{3}$ Pontificale Romanum I, 19-22.

${ }^{4} \mathrm{Z}$ uwagi na brak dostępu do wszystkich pomieszczeń za klauzurą badania nie objęły części stolarki, lecz podziękowania i ukłony składam na ręce wszystkich przełożonych, księży, ojców i sióstr zakonnych w Jarosławiu za życzliwe udostępnienie obiektów i umożliwienie badań.
} 
kościół pw. Świętego Ducha z końca XVII wieku, barokowe założenia kościelnoklasztorne: oo. Dominikanów (wcześniej jezuitów) i oo. Franciszkanów (OFM), a także XIX wieczne założenie klasztorne z kaplicą Sióstr Niepokalanego Poczęcia Najświętszej Marii Panny. Niestety w dawnym Opactwie Panien Benedyktynek z początku wieku XVII wszystkie drzwi uległy zniszczeniu i dawne wyroby stolarskiego rzemiosła się nie zachowały.

Pomimo wielu opracowań dotyczących dziejów Jarosławia i poszczególnych obiektów sakralnych stolarka drzwiowa nie znalazła szerszego zainteresowania. Jan Sas Zubrzycki w opracowaniu pt. Miasto Jarosław i jego zabytki ujął jedynie rysunek kłódki do jarosławskiej fary, obecnie kolegiaty Bożego Ciała (drzwi nie zachowały się) ${ }^{5}$. Natomiast Mieczysław Orłowicz w przewodniku po Jarosławiu z 1921 roku pt. Jarosław jego przeszłość $i$ zabytki, w opisie historii założenia kościelno klasztornego oo. dominikanów opisał drewniany portal prowadzący do zakrystii kościoła pw. Matki Bożej Bolesnej z rzeźbą Michała Archanioła oraz wymienił jako cenne drzwi do zakrystii ${ }^{6}$.

\section{Stolarka drzwiowa w obiektach sakralnych Jarosławia}

Do najstarszych zabytków w jarosławskich obiektach sakralnych należą drzwi zachowane w kościółku pw. Sw. Ducha przy ul. Grunwaldzkiej. Kościół wzniesiony został po 1698 roku w miejscu drewnianej kaplicy Św. Krzyża jako kościół szpitalny, za murami miasta, w bezpośrednim sąsiedztwie szpitala dla ubogich i chorych. Do jego wnętrza prowadziły drzwi w elewacji bocznej (w stosunku do drogi biegnącej w stronę miasta). Drzwi zachowały się do dnia dzisiejszego, lecz są nieużytkowane i przysłonięte drugimi drzwiami drewniany$\mathrm{mi}^{7}$. Pochodzą one z końca wieku XVII, są to drzwi deskowe, z dwoma szpungami, a od zewnętrznej strony obite kutymi blachami, które tradycyjnie wzmacnia kratownica z pasów w układzie na romb, przybitych ćwiekami o kolistych główkach. Wokół skrzydła rozciąga się ozdobny szeroki pas blach podkreślający ich kształt - formę prostokąta zamkniętego łukiem odcinkowym. Zawieszone są one na hakach murowych i dwóch zawiasach pasowych z wydłużoną tarczką u nasady i kolistym zakończeniem. Zamek skrzynkowy występujący w drzwiach, zamknięty $\mathrm{w}$ formie trójliścia ozdobiony został motywami wici i hierogramem IHS, w którym przestawione zostały litery. Lustrzane odbicie litery S i przestawienie jej na początek hierogramu świadczy tylko o tym, iż wykonawca nie zaplanował dobrze rozmieszczenia liter i zapewne nie był światłym uczonym, lecz prostym

\footnotetext{
${ }^{5}$ Zubrzycki J.S., Miasto Jarosław i jego zabytki., Kraków 1903, s. 40. Więcej na temat stolarki w kolegiacie odnajdziemy w maszynopisach ks. Jakuba Makary opisujących dzieje Parafii łacińskiej w Jarosławiu, lecz dotyczą one stolarki i drzwi w większości nieistniejących, por. Makara J. ks., Parafia Łacińska w Jarosławiu, t. II, Jarosław 1950, s. 388-389, mszps w zb. Archiwum Muzeum Kamienica Orsettich w Jarosławiu (dalej AMJ).

${ }^{6}$ Orłowicz M., Jarosław jego przeszłość i zabytki, Lwów 1921, s. 131.

${ }^{7} \mathrm{~W}$ czasie kiedy kościółek należał do ewangelików przy tych drzwiach występował rodzaj ganku. Na fotografii z 1939 r. występują już tylko drzwi opierzane deseczkami, ułożonymi koncentrycznie wokół czterech rombów. Por. AMJ, sygn. 447. Obecne drzwi deskowe wykonane zostały na wzór wcześniejszych podczas remontu kościoła w latach 80. XX w.
} 
rzemieślnikiem. Zamek przy montażu został odwrócony o $180^{\circ}$. Pierwotnie drzwi musiały funkcjonować jako drzwi główne do kościoła, bowiem jego korpus połączony był ze szpitalem dla ubogich dobudówką. Została ona rozebrana, kiedy świątynia przeszła w ręce ewangelików. Drzwi w tej elewacji szczęśliwie pozostały i pełnią obecnie rolę głównego wejścia. Są to barokowe drzwi bez odrzwi, deskowoszpungowe, jednoskrzydłowe, od zewnątrz obite blachami, analogicznie do drzwi bocznych, lecz zawieszone na trzech hakach murowych i pasowych zawiasach. Górny i dolny zawias z owalną tarczką u nasady zakończony jest dwoma grocikami, środkowy nieco krótszy i prosty. Drzwi nie uniknęły z biegiem czasu ingerencji, odnowione zostały w ramach prac remontowych kościoła w latach 80 . XX wieku.

Opatrzone są one dwoma zamkami. Dolny skrzynkowy prawdopodobnie wykonany był do innego obiektu i w trakcie montażu do skrzydła drzwiowego odwrócony o $180^{\circ}$. Wskazuje na to wyraźnie mechanizm jak i hierogram IHS. Puszka ma kształt zbliżony do kwadratu. Górny zamek skrzynkowy jest późniejszy i można go datować na początek XIX wieku. Został on zamontowany dopiero w trakcie renowacji drzwi w ramach wspomnianego remontu kościoła.

Barokowe, lecz już z początku XVIII wieku, drzwi zewnętrzne zachowały się w kościele oo. dominikanów, wcześniej jezuitów, zwanym wówczas kościołem Najświętszej Marii Panny w Polu. Oryginalne drzwi znajdują się w transepcie od północnej i południowej strony kościoła. Są to drzwi dwuskrzydłowe, bez odrzwi, deskowo-szpungowe, zabezpieczone od zewnętrznej strony kutymi blachami. Analogicznie wzmocnione trzema szpungami o sfazowanych krawędziach, o długości równej niemal całej szerokości skrzydeł drzwiowych ${ }^{8}$. Zawieszone są one na hakach murowych i pasowych zawiasach ozdobionych zygzakiem, a zamykane od wnętrza zaporą, wsuwaną w całości w otwór znajdujący się w ścianie kościoła.

1)

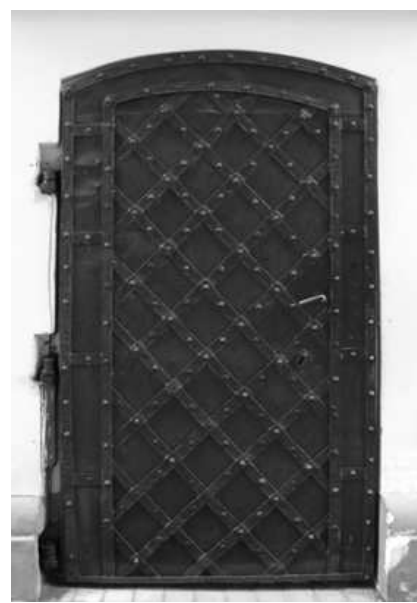

2)

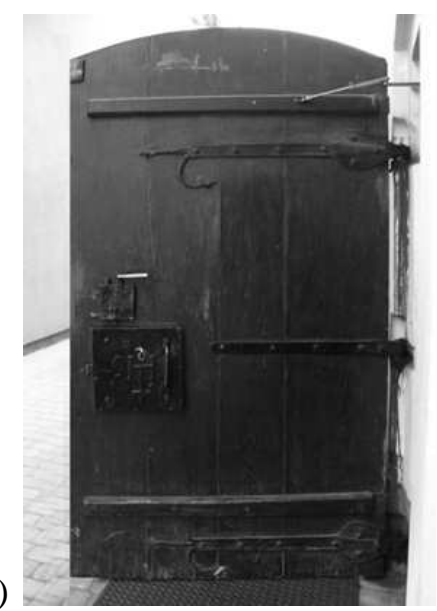

Fot.1-2. Drzwi główne z kościoła pw. Św. Ducha

Pfotos 1-2. The main door from the church dedicated to Holy Spirit

\footnotetext{
${ }^{8} \mathrm{~W}$ drzwiach od południa środkowe szpungi zostały ścięte pod pasowe zawiasy, co przemawia za faktem, iż haki murowe musiały być już przygotowane wcześniej i montaż zawiasów był do nich dostosowany.
} 


\section{3)}

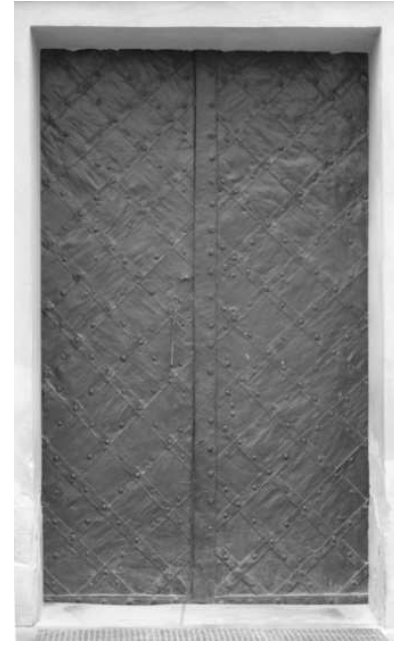

4)

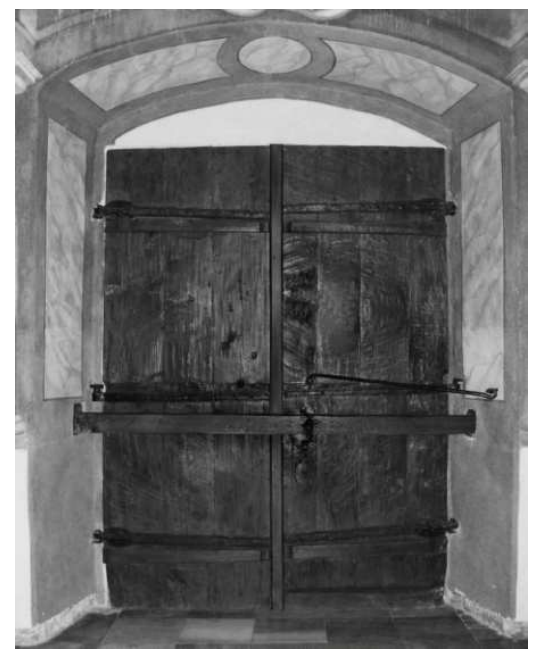

Fot. 3-4. Drzwi w transepcie kościoła pw. Matki Bożej Bolesnej

Pfotos 3-4. The door in transept the church dedicated to Our Lady of Sorrows

W zaporze wrót południowych zachowała się kluczka do jej wyciągania. Obie zapory zamykane są oryginalnymi kłódkami z około połowy XIX wieku (klucze niestety nie zachowały się, ale nowo wykonane dostosowane zostały do mechanizmów kłódek i są użytkowane). Drzwi były zamykane dodatkowo zamkiem puszkowym. Świadczą o tym ślady na drewnie i otwory pod klucz. Wrota poddane zostały konserwacji ${ }^{9}$.

Podobne pod względem formy i konstrukcji są wrota pomiędzy kruchtą, a nawą główną, lecz podczas renowacji w latach 80 . XX wieku drewniana zapora została zastąiona stalowym profilem kwadratowym. Drzwi mają wymieniony również górny i dolny zawias lewego skrzydła. Oryginalna kłódka służy do zamykania wstawionej w tym czasie kraty zabezpieczającej wnętrze. $Z$ uwagi na wartości historyczne i walory zabytkowe oraz stan zachowania wymagają konserwacji.

Ważne z uwagi na funkcję użytkową, jak ozdobną są drzwi w prezbiterium kościoła; od północy prowadzące pierwotnie do skarbca, i od południa prowadzące do zakrystii. Te jednoskrzydłowe drzwi deskowe wzmocnione dwoma szpungami zostały zwieszone na trzech hakach i zawiasach pasowych. Drzwi do skarbca opatrzone są zamkiem puszkowym działającym do dzisiejszych czasów. W drzwiach do zakrystii pozostał tylko ślad po zamkniętym trójliściem zamku puszkowym. Szczególnie ozdobnie potraktowane jest obicie z blach. Pasy tworzące kratownice w układzie romboidalnym ozdobione są gwiazdkowymi ćwiekami, z których część (otaczająca wokół skrzydło drzwiowe) montowana jest na podkładkach w kształcie sześcio lub siedmiopłatkowych rozetek.

\footnotetext{
${ }^{9} \mathrm{~W}$ trakcie konserwacji malowideł ściennych w kaplicach św. Jana Nepomucena i Serca Jezusowego wykonane zostały jednocześnie prace przy drzwiach. Usunięto wtórne nawarstwienia malarskie i odsłonięto fakturę ręcznie obrabianego drewna, oczyszczono i zabezpieczono okucia i elementy metalowe. Drzwiom przywrócono pierwotny wygląd. Brak dokumentacji po wykonaniu prac.
} 
Zakrystia posiada kompleksowo zachowane wyposażenie z 1 poł. XVIII wie$\mathrm{ku}$, począwszy od posadzki, przez meble, boazerię oraz wystrój malarski. W tym znakomitym, przemyślanym pod względem formalnym i ikonograficznym wnętrzu, znajdują się również oryginalne drzwi podwójne, prowadzące do klasztoru. Wewnętrzne, ramowo-płycinowe i jednoskrzydłowe, pochodzą z XIX wieku i są dostosowane do całego wyposażenia meblowego - zespołu komód, szaf i boazerii, dekorowanych warstwą malarską $\mathrm{w}$ kolorze czerni $\mathrm{z}$ detalami pozostawionymi w kolorze drewna. Ich prostokątne płyciny ujęte są wąskimi prętawinami pozbawionymi warstwy malarskiej, a dekorację stanowi wpisany centralnie motyw rombu. Opracowane są one analogicznie od strony awersu i rewersu, zawieszone na zawiasach czopowych i zamykane skrzynkowym zamkiem z żeliwną klamką. Głębokie ościeżnice polichromowane na czarno zdobione są w górnej części prostokątnymi płycinami ze ściętymi górą narożnikami. Drzwi zewnętrzne do zakrystii pochodzą z 1 poł. XVIII wieku, dekorowane są barwną, swobodnie malowaną, błękitną marmoryzacją. Są to drzwi o konstrukcji deskowej, wzmacnianej pseudopłycinową dekoracją z obydwu stron, złożoną z czterech prostokątnych płycin o wciętych wklęsło narożach. Drzwi pierwotnie zawieszone były na dwóch pasowych zawiasach ${ }^{10}$. Od rewersu występuje w nich klamka w formie gałki, od awersu klamka ujęta żelaznym, wyciętym ozdobnie szyldem. Drzwi ujęte są obecnie skromną opaską, lecz wcześniej otoczone były ozdobnym portalem zwieńczonym rzeźbą Michała Archanioła zabijającego smoka. Wskazywał on wchodzącym do zakrystii zakonnikom, kierunek działania i nauczania - walkę ze złem - szatanem, jako drogę do królestwa Bożego. Szczęśliwie rzeźba zachowała się, lecz nie wiadomo kiedy została ustawiona nad innym wejściem $w$ korytarzu klasztornym ${ }^{11}$. Jej stan zachowania utrudniał w pierwszej chwili nawet atrybucję, bo rzymska zbroja, spódnica z pasków, a także hełm i sandały na nogach, wygięcie torsu wskazywały bardziej na postać św. Floriana. Po demontażu rzeźby z portalu celem konserwacji i dokładnej analizie nie było wątpliwości co do atrybucji postaci. Jednocześnie stwierdzono konieczność rekonstrukcji brakujących elementów. Rzeźba przedstawia Michała Archanioła stojącego na smoku z mieczem ognistym w prawej dłoni i łańcuchem spowijającym smoka w lewej. Ubrany jest w niebieską sukienkę oraz rzymską zbroję (puklerz srebrzony, paski spódnicy złocone). Rozpostarte za plecami skrzydła i laserowany miecz ognisty zostały zrekonstruowane na podstawie analogii stylistycznych i formalnych, a pierwotne warstwy malarskie odsłonięte spod przemalowań i scalone kolorystycznie ${ }^{12}$. Konserwacja tej rzeźby była wynikiem podjęcia prac przy drzwiach w korytarzu klasztornym oo. dominikanów. Wyraźnie przemalowane i jednocześnie obite płytami pilśniowymi polichromowanymi na wzór szmaragdowej marmoryzacji nie zapowiadały się tak okazale. Demontaż i pełna konserwacja przywróciły drzwiom pierwotny wygląd plastyczny

10 Drzwi zapewne zostały umieszczone w tym miejscu wtórnie. Zawiasy zostały obcięte i skrzydło zawieszono na nowych zawiasach czopowych.

${ }^{11}$ W 1921 roku występowała jeszcze nad wejściem do zakrystii, lecz ma pochodzić z portalu prowadzącego do biblioteki zakonnej na emporze, por. fot. Orłowicz M., Przewodnik ... op.cit. s. 131.

${ }^{12}$ Pełną konserwację przeprowadziła firma z Krakowa: Agnieszka Luboń Radwańska, Piotr Radwański. Konserwacja Zabytków w roku 2008. Brak dokumentacji powykonawczej. 
i estetyczny, a jednocześnie właściwy stan zachowania. Są to jedyne w Jarosławiu barokowe drzwi ażurowe. Ramiaki ujmujące kompozycję z bujnych akantowych liści polichromowane są w kolorze oliwkowej zieleni. Natomiast snycerska liściasta oprawa $\mathrm{z}$ centralnie usytuowanym motywem IHS po stronie rewersu jest srebrzona, a awersu w całości złocona złotem płatkowym. Oddają one w pełni barokowy splendor jezuickiego wnętrza klasztornego w Jarosławiu, którego ściany pokrywają w części znakomite malowidła ścienne Adama Swacha.

Stolarkę o tradycyjnej formie barokowej reprezentują drzwi w klasztornych celach. Są to drzwi jednoskrzydłowe, ramowo-płycinowe, zawieszone na esowych zawiasach i hakach do drewna z podpórką. Oryginalne, choć nie ozdobne, wymagają pełnej konserwacji.

XIX wieczne drzwi w kościele oo. dominikanów prowadzą także na chór. Skromne jednoskrzydłowe, ramowo-płycinowe drzwi pełne ozdabiają koliste guzy w narożach środkowej płycinki, a także skromny portal zwieńczony wolutowym naczółkiem z krzyżykiem na osi i sterczynami po bokach. Eklektyczna stolarka, z tego samego okresu, występuje również w głównym wejściu do klasztoru od strony wschodniej. Jednoskrzydłowe drzwi z prześwitem i nadświetlem ujęte są skromnym portalem zamknięty trójkątnym naczółkiem podbudowanym wolutowymi motywami po bokach. W klasztorze uwagę zwracają jeszcze drzwi w korytarzu prowadzącym do zakrystii pochodzące z 1 ćw. XX wieku. Są typowymi drzwiami ramowo-płycinowymi z prześwitem, na czopowych zawiasach, lecz uwagę skupia przeszklenie $\mathrm{z}$ trawionej szyby. Na szybie znajduje się secesyjna dekoracja kwiatowa, a górą napis „Apteka Pod Opatrznością Boską”. Apteka ta znajdowała się na rogu ulic Lubelskiej i Grunwaldzkiej, należała do Feliksa i Heleny Wojciechowskich i funkcjonowała już w 1912 roku $^{13}$. W tym czasie szyby trawione były sprowadzone do Jarosławia z warsztatów szklarskich we Lwowie, więc były towarem deficytowym i nie każdy mógł sobie na nie pozwolić. Brak jest informacji jak szyba znalazła się w klasztorze.

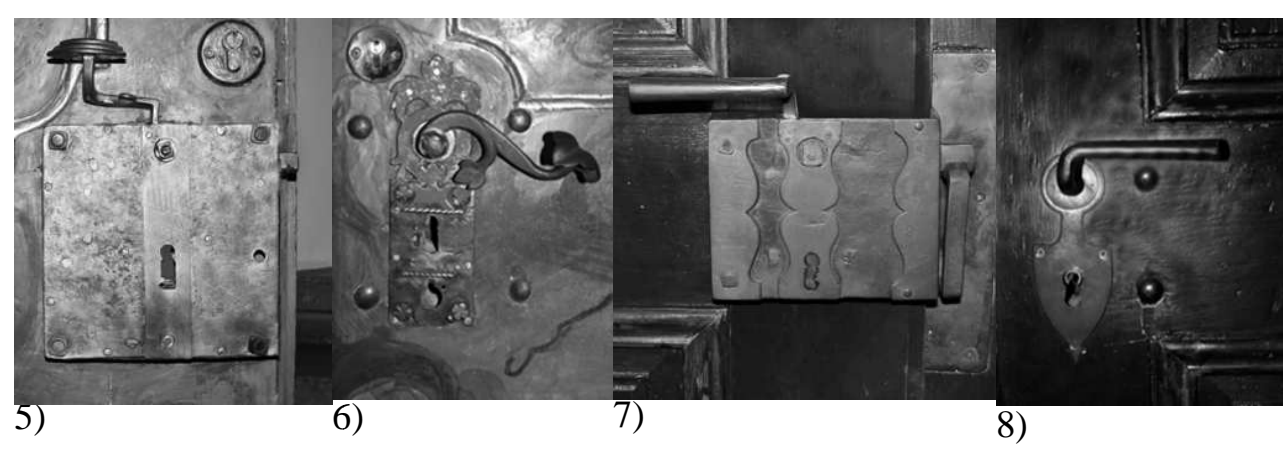

Fot. 5-8. Zamki i klamki w zakrystii przy kościele pw. Matki Bożej Bolesnej

Photos 5-8. The locks and door handles in the sacristy by the church dedicated to Our Lady Sorrows

${ }^{13}$ Por. Zięba Z., Dawni aptekarze jarosławscy (w:) Biuletyn Informacyjny Miasta Jarosławia, nr 10, 2008, s. 21-22. 
Z eklektyczną stolarką spotykamy się także w kościele i klasztorze oo. franciszkanów przy ul. Jana Pawła II. Mimo, iż barokowe założenie zachowało się $\mathrm{z}$ niemal kompletnym oryginalnym wyposażeniem, stolarka drzwiowa uległa wymianie, w dużej mierze na początku XX wieku. Reguła franciszkańska zapewne nie pozwoliła na bogato dekorowane drzwi i można przypuszczać, że te pierwotne były jeszcze skromniejsze od obecnych, wykonanych w duchu stylów historyzujących. Do kościoła prowadzą masywne dwuskrzydłowe drzwi ramowo-płycinowe, których płyciny zdobią snycerskie dekoracje z motywem herbu franciszkanów. Wyróżniają się one także ozdobną klamką z motywem żołędzi i powycinanym finezyjnie szyldem (chociaż wtórna posiada interesujący wygląd). W kościele zachowały się ponadto dwuskrzydłowe drzwi w kruchcie, konstrukcji ramowo-płycinowej, z prześwitami i nadświetlem. Ujęte są one drewnianym portalem z gierowanym naczółkiem i sterczynami po bokach. Prześwity rozczłonkowane szprosami z motywem karo pośrodku przeszklone zostały szkłem białym, szlifowanym, natomiast prostokątne nadświetle, rozdzielone słupkiem oraz pionowymi i poziomymi szprosami, szkłem białym i barwionym w masie: kobaltowym i rubinowym. ${ }^{14}$ Uwagę zwraca także dwoje drzwi w prezbiterium, prowadzących do klasztoru, podobnych pod względem konstrukcji i formy. Pierwsze ozdobione są monogramem maryjnym, drugie motywem herbowym zakonu franciszkanów. Są to drzwi jednoskrzydłowe, ramowopłycinowe, w których ramiak w osi pionowej wraz z poprzecznym - górnym tworzą krzyż z wpisaną na skrzyżowaniu stylizowaną dekoracją snycerską, ujętą kolistym otokiem. Utworzone płyciny ujmują wąskie profilowane prętawiny.

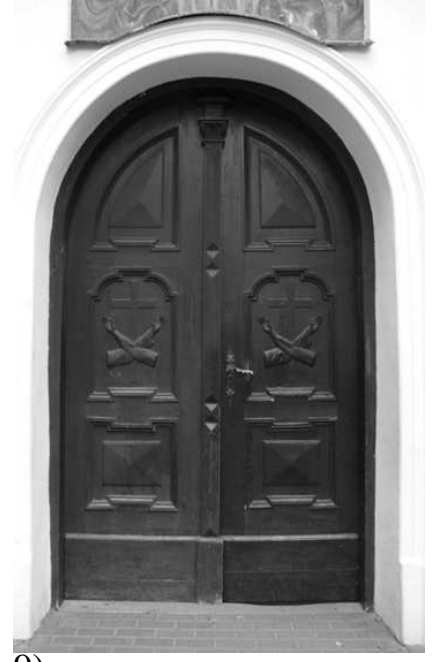

9)

Fot. 9-11. Drzwi z kościoła i klasztoru oo. Franciszkanów (OFM)

Pfotos 9-11. The doors from the church and monastery of the Franciscan Reformatory

\footnotetext{
${ }^{14}$ Niestety skrzydła drzwiowe są nowe. Chociaż wykonane na wzór wcześniejszych, nie powtarzają technologii wykonania i przeszklenia, które było analogiczne do szybek w nadświetlu.
} 
Drzwi w kościele oraz w klasztorze powstały na początku XX wieku w ramach prac remontowych i renowacyjnych założenia ${ }^{15}$. Wykonane zostały $\mathrm{z}$ drewna dębowego, jako ościeżnicowe, konstrukcji ramowo-płycinowej i zawieszone na czopowych lub tarczowych zawiasach. Drzwi zewnętrzne do klasztoru i wewnętrzne w furcie ujęte są skromnymi portalami z trójkątnymi naczółkami. Najciekawsze są drzwi w furcie, $\mathrm{z}$ ażurową, żelazną kratką do komunikowania się, a także mechanizmem pozostałym po dzwonku, który niestety został zdemontowany. Świadectwem jest pozostający w opasce drzwiowej „kołowrotek”. Drzwi te zawieszone są na tarczowych zawiasach na kształt wachlarzy i opatrzone skrzynkowym zamkiem ozdobionym ażurową rozetą. W klasztorze zachowało się także dwoje eklektycznych drzwi prowadzących do chóru zakonnego. W krosnowych odrzwiach, ramowo- płycinowe skrzydła zawieszone na czopowych zawiasach ujęte są po bokach pilastrami wspierającymi ślemię i półkoliste nadświetle. Zostało one rozczłonkowane szprosami na kształt półrozety i przeszklone szkłem białym i barwionym w masie. Drugie, mniejsze drzwi z chóru, są również krosnowe i ramowo-płycinowe, lecz pełne i zamknięte nadświetlem o łuku odcinkowym z wpisanym pośrodku motywem koła.

W latach 1873-1875 wzniesione zostało w Jarosławiu, na miejscu dawnego folwarku jezuickiego, założenie klasztorne Sióstr Niepokalanego Poczęcia NMP. Do klasztoru prowadzi drewniany ganek ze skromną, oryginalną stolarką z czasu budowy. Zachowały się w nim oryginalne przeszklenia, a w drzwiach zawiasy oraz klamka z ozdobnym szyldzikiem. Drzwi wejściowe do klasztoru są podwójne, dwuskrzydłowe, ramowo-płycinowe, pełne. Pierwotna stolarka zachowała się także w wejściu do zakrystii przy kaplicy klasztornej (od strony dziedzińca wewnętrznego). Są to drzwi podwójne, jednoskrzydłowe, pełne, z nadświetlem. Zewnętrzne - stanowią jedyne zachowane w klasztorze drzwi deskowe, wzmocnione dwoma szpungami i opierzone deseczkami ułożonymi koncentrycznie wokół rombu. Zawieszone są one na hakach do drewna $\mathrm{z}$ podpórką. $\mathrm{W}$ wnętrzu klasztoru wyróżniają się drzwi prowadzace do kaplicy - dwuskrzydłowe, ramowopłycinowe, pięciopoziomowe, $\mathrm{z}$ krzyżykiem $\mathrm{w}$ zwieńczeniu. Ich płyciny ujęte są szerokimi prętawinami ${ }^{16}$. Uwagę zwracają także drzwi krosnowe w ściankach stanowiących przepierzenie klasztornych korytarzy. Są one w większości przeszklone $\mathrm{w}$ górnych partiach skrzydeł, posiadają oryginalne okucia, czopowe zawiasy i mosiężne klamki. W klasztorze zachowała się również oryginalna stolarka ramowo-płycinowa $\mathrm{w}$ wejściach do cel oraz innych pomieszczeń pozostających wyłącznie do dyspozycji sióstr niepokalanek.

W stosunkowo dużym zespole stolarki wyróżniają się drzwi, a właściwie wrota do kaplicy grobowej na pobliskim cmentarzu klasztornym, gdzie siostry chowane są do dnia dzisiejszego. W zamknięty półkoliście otwór wstawione są dwuskrzydłowe drzwi ramowo-płycinowe z nadświetlem. Dolne prostokątne płyciny dekorowane są pośrodku motywem rozetki, górne przecięte na skos ramia-

${ }^{15}$ Gotfried K., Kościół i klasztor ojców Reformatów w Jarosławiu, Jarosław, 1934, s. 51.

${ }^{16}$ Drzwi zostały w ostatnich latach odnowione poprzez usunięcie nawarstwień malarskich, prawdopodobnie pierwotnie były zabezpieczone warstwą kryjącą, obecnie lakierem bezbarwnym. 
kami wyciętymi od dołu łukiem wklęsłym, symetrycznie względem listwy przymykowej. Listwa kanelowana w partii cokołowej zwieńczona jest w górze toczona głowicą ze żłobieniami. Ciężkie wrota zawieszone na krzyżowych zawiasach, zamykane są żeliwnymi klamkami i wpuszczanym zamkiem. W nadświetlu brak jest przeszklenia, występuje tylko krata z płaskownika, z motywem krzyża na osi oraz ślimacznicami i kołami w przyłuczu.

Na zakończenie słów kilka o drzwiach w jednym z najstarszych kościołów, chociaż stolarka w nim jest najmłodsza spośród omawianej. Niestety w kościele pojezuickim, obecnej kolegiacie pw. Bożego Ciała, pożar w 1862 roku strawił wiele elementów wyposażenia i wystroju. Do najstarszych zatem należą drzwi w prezbiterium kościoła. Są one formalnie i stylistycznie połączone ze stallami usytuowanymi po bokach wejścia. Wykonał je Stanisław Cholewa z Jarosławia w 1912 roku i zapewne on jest autorem stolarki ${ }^{17}$, której dolne płyciny zdobi stylizowana dekoracja snycerska o motywach rokokowych, kratki regencyjnej i stylizowanych muszli. (Podobnie dekorowane są ościeżnice.) Są to drzwi dwuskrzydłowe z prześwitami przeszklonymi szkłem ornamentowym. Prześwity $\mathrm{w}$ dolnej partii były pierwotnie zabezpieczone poziomymi prętami metalowymi (obecnie wycięte).

W zakrystii, dobudowanej do kościoła w 1928 roku (po rozbiórce części dawnego kolegium jezuickiego) znajdują się wahadłowe drzwi ramowo-płycinowe z prześwitami i nadświetlem. Ponadto oryginalne drzwi prowadzą do „nowej i starej zakrystii”. Te z ,nowej” - dwuskrzydłowe, ramowo-płycinowe, pełne utrzymane są w duchu stolarki klasycyzującej, z promieniście puklowaną pośrodku elipsą. Natomiast dwuskrzydłowe drzwi ze „starej” zakrystii wyróżniają płyciny z wciętymi narożami.

Podobne do wyżej wymienionych drzwi wahadłowych znajdują się także przy bocznym wejściu do kościoła i pełnią analogiczną funkcję wiatrołapu.

\section{Podsumowanie}

Z dokonanej syntetycznej analizy zachowanej historycznej stolarki drzwiowej w obiektach sakralnych wynika, iż mimo tak dużego procentu zniszczenia oryginałów zachowały się jednostkowe przykłady drzwi barokowych oraz historyzujących - łączących elementy późniejszych stylów. Naturalnie ich rolą nadrzędną jest funkcja użytkowa - zabezpieczenie obiektu, lecz pełnią one także rolę ozdoby zarówno elewacji jak i wnętrza, są granicą pomiędzy przestrzeniami o różnym znaczeniu. Urastają one do rangi symbolu i znaku pamięci. Dlatego omawiane drzwi powinny podlegać ścisłej ochronie, nawet jeżeli ich forma nie przedstawia wysokiej rangi artystycznej. Skoro przetrwały one dwa, trzy wieki i funkcjonują do dnia dzisiejszego, potwierdzają, iż „stare” drzwi przedstawiają wysoką jakość materiału i wykonania. Historyczna stolarka wymaga inwentaryzacji, dalszych badań, a przede wszystkim konserwacji i dbałości o zachowanie jej dla przyszłych pokoleń.

17 Turczak Ł., Stalle, Karta ewidencyjna zabytku ruchomego, zb. Archiwum Wojewódzkiego Konserwatora Zabytków w Przemyślu. 
Wykaz historycznej stolarki drzwiowej zachowanej w obiektach sakralnych na terenie miasta Jarosławia Kościół pw. Św. Ducha

1. Drzwi główne, k. XVII w., bez odrzwi, jednoskrzydłowe, deskowo-szpungowe, obite blachami, na hakach murowych, zawiasach pasowych, zamki skrzynkowe, XVIII w.(?) i XIX w.

2. Drzwi boczne, k. XVII w., bez odrzwi, jednoskrzydłowe, deskowo-szpungowe, obite blachami, na hakach murowych, zawiasach pasowych, zamek skrzynkowy, k. XVII w.

Zespół kościelno-klasztorny oo. Dominikanów

1. Drzwi zewnętrzne w transepcie (od północy), 1 ćw. XVIII w., bez odrzwi, dwuskrzydłowe, deskowoszpungowe, obite blachami, na hakach murowych, zawiasach pasowych, z zaporą drewnianą, zamykane kłódka (klucz nowy, dorobiony do oryginalnego mechanizmu).

2. Drzwi zewnętrzne w transepcie (od południa), j.w.

3. Drzwi wewnętrzne z kruchty do nawy głównej, 1 ćw. XVIII w., bez odrzwi, dwuskrzydłowe, deskowoszpungowe, obite blachami, na hakach murowych, zawiasach pasowych. Brak oryginalnej zapory.

4. Drzwi wewnętrzne z prezbiterium do skarbca, 1 ćw. XVIII w., jednoskrzydłowe, deskowo-szpungowe, obite blachami, na zawiasach pasowych, hakach do drewna, zamek skrzynkowy, 1 ćw. XVIII w., klucz oryginalny.

5. Drzwi wewnętrzne z prezbiterium do zakrystii, 1 ćw. XVIII w., bez odrzwi, jednoskrzydłowe, deskowoszpungowe, obite blachami, na zawiasach pasowych, ślady na desce po zamku skrzynkowym zamkniętym w formie trójliścia.

6. Drzwi na chór, k. XIX w., ościeżnicowe, jednoskrzydłowe, pełne, zawiasy czopowe, zamek wpuszczany.

7. Drzwi zewnętrzne do klasztoru, k. XIX w., ościeżnicowe, jednoskrzydłowe, ramowo-płycinowe z prześwitem i nadświetlem, zawiasy czopowe.

8. Drzwi z zakrystii do klasztoru (I), 2 poł. XIX w., ościeżnicowe, jednoskrzydłowe, ramowo-płycinowe, zawiasy czopowe, zamek skrzynkowy, kluczynka w formie tarczy ostro zakończonej dołem.

9. Drzwi z zakrystii do klasztoru (II), 1 ćw. XVIII w., ościeżnicowe, jednoskrzydłowe, deskowe opierzane dekoracją pseudopłycinową, zawiasy pasowe (ścięte), nowe zawiasy: czopowe, zamek skrzynkowy, szyld wycięty dekoracyjnie.

10. Drzwi w korytarzu klasztornym, 1 poł. XVIII w., ościeżnicowe, jednoskrzydłowe, ażurowe, zawiasy szarnierowe, klamka współczesna.

11. Drzwi w klasztorze (z napisem w szybie), 1 ćw. XX w., ościeżnicowe, jednoskrzydłowe, ramowo-płycinowe, z prześwitem przeszklonym szkłem białym trawionym, zamek i klamka współczesne.

12. Drzwi do cel klasztornych, 1 poł. XIX w. (?), ościeżnicowe, jednoskrzydłowe, ramowo-płycinowe, pełne, zawiasy esowe, klamki współczesne.

Zespół kościelno-klasztorny oo. Franciszkanów (OFM)

1. Drzwi główne do kościoła, p. XX w., ościeżnicowe, dwuskrzydłowe, ramowo-płycinowe, zawiasy czopowe, zamek wpuszczany.

2. Drzwi boczne do kościoła, XX w., ościeżnicowe, jednoskrzydłowe, ramowo-płycinowe, zawiasy czopowe, zamek wpuszczany.

3. Drzwi z kruchty do nawy głównej, p XX w., dwuskrzydłowe, ramowo-płycinowe z prześwitami i nadświetlem, zawiasy czopowe.

4. Drzwi z prezbiterium do klasztoru (I) p. XX w., ościeżnicowe, jednoskrzydłowe, ramowo-płycinowe, pełne, z monogramem maryjnym, zawiasy czopowe, zamek wpuszczany

5. Drzwi z prezbiterium do klasztoru (II) p. XX w., ościeżnicowe, jednoskrzydłowe, ramowo-płycinowe, pełne, $\mathrm{z}$ herbem zakonu franciszkanów, zawiasy czopowe, zamek wpuszczany .

6. Drzwi do furty klasztornej, p. XX w., ościeżnicowe, jednoskrzydłowe, ramowo-płycinowe, pełne, zawiasy tarczowe, zamek skrzynkowy.

7. Drzwi z furty do klasztoru, j.w.

8. Drzwi w klasztorze na dawną klatkę schodową, p. XX w., ościeżnicowe, dwuskrzydłowe, ramowo-płycinowe, z prześwitami, zawiasy czopowe, zamek wpuszczany.

9. Drzwi w chórze zakonnym (I), p. XX w., krosnowe, z nadświetlem, dwuskrzydłowe, ramowo-płycinowe z prześwitami, zawiasy czopowe, zamek wpuszczany

10. Drzwi w chórze zakonnym (II), p. XX w., krosnowe, z nadświetlem, dwuskrzydłowe, ramowo-płycinowe, pełne, zawiasy czopowe, zamek wpuszczany.

Klasztor Zgromadzenia Sióstr Niepokalanego Poczecia Najświetszej Marii Panny

1. Drzwi zewnętrzne do zakrystii przy kaplicy klasztornej, k. XIX w., ościeżnicowe, deskowo-szpungowe, opierzane, na hakach do drewna z podpórką, zamek wpuszczany, klamka żeliwna.

2. Drzwi do ganku klasztornego, k. XIX w., jednoskrzydłowe, ramowo-płycinowe, z prześwitem, zawiasy czopowe, zamek wpuszczany, klamka mosiężna z ozdobnym szyldem.

3. Drzwi z ganku do klasztoru, k. XIX w., ościeżnicowe, podwójne, dwuskrzydłowe, ramowo-płycinowe, pełne, zawiasy czopowe, zamki wpuszczane, klamki mosiężne, kluczynki ozdobne.

4. Drzwi do kaplicy klasztornej (I), k. XIX w., ościeżnicowe, dwuskrzydłowe, ramowo-płycinowe, pełne, zawiasy czopowe, zamek wpuszczany, klamka mosiężna.

5. Drzwi do kaplicy klasztornej (II), k. XIX w., ościeżnicowe, dwuskrzydłowe, ramowo-płycinowe, pełne, $\mathrm{z}$ nadświetlem, zawiasy czopowe, zamek wpuszczany, klamka mosiężna. 
6. Drzwi do kaplicy grobowej na terenie przyklasztornego cmentarza, 1 poł. XX w., ościeżnicowe, dwuskrzydłowe, z nadświetlem, ramowo-płycinowe, pełne, zawiasy krzyżowe, zamek wpuszczany, klamki żeliwne.

Kolegiata Bożego Ciała

1. Drzwi w prezbiterium, 1912 r., Stanisław Cholewa, krosnowe, dwuskrzydłowe, z nadświetlem, ramowopłycinowe, z prześwitami, szyby ornamentowe, klamka mosiężna.

2. Drzwi przy wejściu bocznym do kościoła, $1.30 \mathrm{XX}$ w., krosnowe, wahadłowe, dwuskrzydłowe, z nadświetlem, ramowo-płycinowe, z prześwitami, klamki w formie uchwytów mosiężne.

3. Drzwi przy wejściu do zakrystii, j.w.

4. Drzwi do „,nowej zakrystii”, 1.30. XX w., dwuskrzydłowe, ramowo-płycinowe, pełne, zamek i klamka współczesne.

5. Drzwi do „starej zakrystii”, 1.30. XX w., dwuskrzydłowe, ramowo-płycinowe, pełne, zamek wpuszczany, nieużytkowany, klamka współczesna.

\title{
Literatura
}

[1] Forstner D. OSB, hasło: drzwi (w:) Świat symboliki chrześcijańskiej, Warszawa 1990, s. 383-386.

[2] Gotfried K., Kościół i klasztor ojców Reformatów w Jarosławiu, Jarosław, 1934.

[3] Lurker M., Słownik obrazów i symboli biblijnych, Poznań 1989, s. 50-52.

[4] Makara J. ks., Parafia Łacińska w Jarosławiu, t. II, Jarosława 1950, mszps w zb. Archiwum Muzeum Kamienica Orsettich w Jarosławiu.

[5] Orłowicz M., Jarosław. Jego przeszłość i zabytki, Lwów 1921.

[6] Miazek J. ks., Otwarcie drzwi świętych w Roku Jubileuszowym, Warszawskie Studia Teologiczne, T. XIII, 2000, s. 7-16.

[7] Turczak Ł., Stalle, Karta ewidencyjna zabytku ruchomego, zb. Archiwum Wojewódzkiego Konserwatora Zabytków w Przemyślu.

[8] Zięba Z., Dawni aptekarze jarosławscy (w:) Biuletyn Informacyjny Miasta Jarosławia, nr 10, Jarosław 2008.

[9] Zubrzycki J.S., Miasto Jarosław i jego zabytki., Kraków 1903.

\section{HISTORIC WOODWORK DOOR IN JAROSŁAW SACRAL OBJECTS}

\author{
S u m m a r y (Translated by Jarostaw Kiwior)
}

Doors have special meaning for sacred objects, they serve as collateral interior, they are adornment, they define the boundary between the sacred and the profane and grow into a symbol and sign of memory. The aim of the study is to identify and recognize the historic woodwork in Jarosław sacral objects, its analysis in terms of materials science, building construction and decoration techniques, style and iconography and the state of preservation. In Jarosław baroque door unit at the end of the seventeenth and eighteenth centuries has been preserved and historicizing the door of the 2 nd half nineteenth and early twentieth century. Baroque woodwork with original fittings (hinges, hooks, door handles, escutcheons, locks, padlocks, and even preserved keys) the church door represents in the dedicated to Holy Spirit and in the church dedicated to Our Lady of Sorrows. The openwork door to motif 'IHS' at carving frame, which located in the Dominican monastery, pays special attention. Big unit of the original woodwork in the last quarter of the nineteenth century was preserved in the monastery Congregatio Sororum Servularum Beatae Mariae Virginis Immaculatae Conceptae. On the other hand, the firstt half of twentieth century represents a historicizing door of the neo-baroque and rococo woodcarving, which is located in the Franciscans complex church and monastery (Ordo Fratrum Minorum) and the collegiate church dedicated to Corpus Christi. On a scale of high-ranking church-monastery complexes, which occur in Jarosław, preserved original doors are a small but significant group so they deserve protection and undertaking further research.

Keywords: antique/historic woodwork, door, Jarosław, sacral objects

Przestano do redakcji: 26.02 .2015 r.

Przyjęto do druku: 22.06.2015 r.

DOI:10.7862/rb.2015.72 